\title{
Peningkatan Kualitas Pembelajaran IPS melalui Model Pembelajaran Kooperatif Tipe Bamboo Dancing
}

\author{
Romanna Sitindaon \\ SD Negeri 101768 Percut Sei Tuan, Deli Serdang, Indonesia \\ Diterima Pebruari 2017; Disetujui April 2017; Dipublikasikan Juni 2017
}

\begin{abstract}
Abstrak
Tujuan dari penelitian ini adalah untuk meningkatkan keterampilan guru, aktivitas siswa dan hasil belajar siswa setelah guru menggunakan model pembelajaran kooperatif tipe Bamboo Dancing dalam pembelajaran IPS pada siswa kelas IV SD Negeri 101768 Tembung. Jenis penelitian ini adalah penelitian tindakan kelas (PTK) yang terdiri dari 3 siklus, pada setiap siklusnya terdiri dari tahap-tahap PTK. Populasi dalam penelitian ini adalah seluruh peserta didik kelas IV-A yang berjumlah 27 siswa. Teknik analisis data yang digunakan adalah kualitatif dan kuantitatif. Berdasarkan data hasil penelitian terdapat peningkatan kualitas pembelajaran IPS. Keterampilan guru mengalami peningkatan pada siklus I memperoleh skor rata-rata 2,6, siklus II menjadi 3,2 dan siklus III meningkat hingga 3,8. Aktivitas siswa juga menunjukkan adanya peningkatan, pada siklus I memperoleh skor rata-rata 2,3, siklus II skor rata-rata 2,6 kemudian siklus III skor rata-rata mencapai 3,5. Persentase ketuntasan belajar siswa juga mengalami peningkatan yaitu pada siklus I mencapai 44\%, siklus II 67\% dan siklus III 93\%. Dengan demikian dapat disimpulkan bahwa melalui model pembelajaran kooperatif tipe Bamboo Dancing dapat meningkatkan kualitas pembelajaran yang meliputi keterampilan guru, aktivitas siswa, dan hasil belajar siswa pada Mata Pelajaran IPS.
\end{abstract}

Kata Kunci: Belajar dan Hasil Belajar, Model Pembelajaran Cooperative Tipe Bamboo Dancing, Pembelajaran IPS.

\begin{abstract}
The purpose of this study is to improve teacher skills, student activities and student learning outcomes after the teacher using cooperative learning model type Bamboo Dancing in social studies learning in fourth grade students at SD Negeri 101768 Tembung. This type of research is a classroom action research (PTK) consisting of 3 cycles, each cycle consisting of PTK stages. The population in this study were all students of class IV-A which amounted to 27 students. Data analysis techniques used are qualitative and quantitative. Based on data of research result there is improvement of learning quality of IPS. The skills of teachers experienced an increase in cycle I obtained an average score of 2.6, cycle II to 3.2 and cycle III increased to 3.8. Student activity also shows an increase, in cycle I get average score 2,3, cycle II score average 2,6 then cycle III average score reaches 3.5. Percentage mastery learning students also experienced an increase in the first cycle reached 44\%, 67\% cycle II and 93\% 93\% cycle. Thus it can be concluded that through cooperative learning model type Bamboo Dancing can improve the quality of learning that includes teacher skills, student activities, and student learning outcomes in the IPS Subject.
\end{abstract}

Keyword: Learning and Learning Outcomes, Cooperative Learning Model Type Bamboo Dancing, IPS Learning.

How to Cite: Sitindaon. R., (2017), Peningkatan Kualitas Pembelajaran IPS melalui Model Pembelajaran Kooperatif Tipe Bamboo Dancing, Anthropos: Jurnal Antropologi Sosial dan Budaya, 3 (1): 32-36

*Corresponding author:

p-ISSN 2460-4585

E-mail: romannasitindaon@gmail.com

e-ISSN 2460-4593 


\section{PENDAHULUAN}

Berdasarkan Standar Kompetensi dan Kompetensi Dasar Tingkat SD/MI dalam Peraturan Menteri Pendidikan Nasional Nomor 22 tahun 2006 tentang standar isi untuk satuan pendidikan dasar dan menengah bahwa Standar Kompetensi (SK) dan Kompetensi

Dasar (KD) Ilmu Pengetahuan Sosial merupakan salah satu mata pelajaran yang diberikan mulai dari SD/MI/SDLB sampai SMP/MTs/SMPLB. IPS mengkaji seperangkat peristiwa, fakta, konsep, dan generalisasi yang berkaitan dengan isu sosial. Pada jenjang SD/MI mata pelajaran IPS memuat materi geografi, sejarah, sosiologi, dan ekonomi. Mata pelajaran IPS disusun secara sistematis, komprehensif, dan terpadu dalam proses pembelajaran yang menuju kedewasaan dan keberhasilan dalam kehidupan di masyarakat. Dengan mempelajari IPS diharapkan peserta didik akan memperoleh pemahaman yang lebih luas dan mendalam pada bidang ilmu yang terkait. Menurut Wahyudi, IPS adalah mata pelajaran yang menelaah masalah-masalah yang terjadi di masyarakat dengan perkembangan ilmu pengetahuan, teknologi, dan komunikasi. Kajian IPS lebih ditekankan pada masalah-masalah atau gejala sosial budaya yang terdapat di masyarakat dan lingkungannya, pada masa lampau dan masa sekarang dalam rangka mengantisipasi perubahan sosial budaya beserta dampaknya terhadap kelangsungan hidup manusia.

Setelah dilakukan pengamatan pada keterampilan guru, aktivitas siswa ,dan hasil belajar pada mata pelajaran IPS di Kelas IV SD Negeri 101768 terdapat beberapa kendala. Kendala tersebut diantaranya pada saat pembelajaran berlangsung siswa cenderung tidak memperhatikan penjelasan guru. Akibatnya siswa tidak dapat menjawab pertanyaan yang diberikan oleh guru. Pembelajaran masih berpusat pada guru dan belum menggunakan pendekatan inovatif. Berdasarkan hasil belajar IPS di kelas IV SD Negeri 101768 dengan materi sumber daya alam menunjukkan hasil belajar siswa rendah. Dari hasil tes formatif menunjukkan nilai rata- rata 52 dengan nilai tertinggi 80 sedangkan nilai terendah 25. Kriteria Ketuntasan Minimal (KKM) untuk mata pelajaran IPS adalah 70. Dari 27 siswa, hanya 8 siswa $(29,62 \%)$ yang tuntas belajar, sedangkan 19 siswa $(70,38 \%)$ belum mencapai ketuntasan belajar. Dengan kondisi demikian maka diperlukan perbaikan pembelajaran melalui penelitian tindakan kelas. Peneliti dan teman sejawat menetapkan alternatif pemecahan masalah dengan menggunakan model pembelajaran kooperatif tipe Bamboo Dancing untuk meningkatkan kualitas pembelajaran IPS.

Pembelajaran kooperatif tipe Bamboo Dancing dipilih dalam penelitian ini karena melalui model pembelajaran tersebut dapat meningkatkan aktivitas siswa dan menciptakan suasana belajar yang menyenangkan. Menurut Suprijono (2010:98) bahwa metode Bamboo Dancing membuat para siswa termotifasi untuk mempelajari materi dengan baik dan pengetahuan yang diperoleh melalui diskusi di tiap - tiap kelompok besar dapat di objektivikasi dan menjadi pengetahuan yang sama seluruh kelas. Selain itu, siswa berkerja dengan sesama siswa dalam suasana gotong royong dan mempunyai banyak kesempatan untuk mengolah informasi dan meningkatkan ketrampilan berkomunikasi, metode Bamboo Dancing ini bisa digunakan untuk semua tingkatan usia anak didik. Penggunaan metode Bamboo Dancing ini selain meningkatkan kecakapan siswa dalam berkomunikasi juga diharapkan mampu memberi solusi kepada siswa dalam memahami suatu konsep mata pelajaran sehingga dapat meningkatkan hasil belajar mereka

Secara umum tujuan dari penelitian ini adalah untuk Meningkatkan kualitas pembelajaran IPS siswa kelas IV SD Negeri 101768 Tembung. Sedangkan secara khusus penelitian ini bertujuan untuk meningkatkan keterampilan guru dalam pembelajaran IPS, meningkatkan aktivitas siswa dan meningkatkan hasil belajar siswa setelah guru menggunakan model pembelajaran kooperatif tipe Bamboo Dancing dalam pembelajaran IPS pada siswa kelas IV SD Negeri 101768 Tembung. 


\section{METODE PENELITIAN}

Menurut Suyanto (dalam Subyantoro, 2009 : 7 J penelitian tindakan kelas merupakan suatu bentuk penelitian yang bersifat reflektif dengan melakukan tindakan-tindakan tertentu agar dapat memperbaiki dan meningkatkan praktik pembelajaran secara profesional. Adapun rancangan PTK terdiri dari empat tahap yaitu : (1) perencanaan, (2) pelaksanaan, (3) pengamatan, dan (4) refleksi. Penelitian ini terdiri dari 3 siklus, pada setiap siklusnya terdiri dari tahap-tahap PTK. Jenis data yang digunakan adalah data kualitatif dan data kuantitatif.. Populasi dalam penelitian ini adalah seluruh peserta didik kelas IV-A yang berjumlah 27 siswa. Teknik pengumpulan data yang dilakukan pada penelitian ini adalah metode observasi, metode wawancara, metode dokumentasi, dan metode tes. Teknik analisis data yang digunakan adalah kualitatif dan kuantitatif.

\section{HASIL DAN PEMBAHASAN}

Berdasarkan data awal terdapat beberapa kendala dalam pembelajaran IPS di kelas IV SD Negeri 101768 Tembung . Kendala tersebut diantaranya keterampilan guru dan aktivitas siswa rendah sehingga berimbas pada hasil belajar siswa rendah. Upaya untuk memperbaiki kualitas pembelajaran IPS salah satunya dengan menggunakan model pembelajaran kooperatif tipe Bamboo Dancing .

Tahap pelaksanaan, pembelajaran ini dilaksanakan sebanyak tiga kali pertemuan. Pada proses pembelajaran ini siswa dibagi menjadi dua kelompok besar yang dipilih secara heterogen berdasarkan kemampuan siswa dari yang berkemampuan tinggi, sedang dan juga rendah. Sebelum memulai pembelajaran dengan metode Bamboo Dancing,dilaksanakan Pre-test untuk mengetahui kemampuan awal siswa dalam penguasaan meteri fungsi. Berdasarkan tabel 3 dapat disimpulkan bahwa hasil pre-test ( data awal ) sebelum diterapkan metode pembelajaran Bamboo Dancing adalah belum tuntas.

Pada saat pembelajaran dengan menggunakan metode Bamboo Dancing siswa masih belum terbiasa mengikuti pembelajaran ini karena metode ini baru didapatkan siswa sehingga mereka harus memerlukan penyesuaian terlebih dahulu. Siswa masih merasa bingung dengan pembelajaran yang baru diterapkan dalam proses pembelajaran oleh peneliti. Siswa yang terbiasa dengan pembelajaran konvensional mengalami kesulitan ketika diajak untuk belajar aktif. Terlihat pada tabel 2 dan 3 bahwa kenaikan aktivitas siswa dan hasil belajar belum terlalu besar.

Kemudian pada pertemuan selanjutnya dapat terlihat pada tabel 2 dan 3 terjadi kenaikan yang konsisten. Berdasarkan data hasil penelitian terdapat peningkatan kualitas pembelajaran IPS. Keterampilan guru mengalami peningkatan pada setiap siklusnya, pada siklus I memperoleh skor rata-rata 2,6. Pada siklus II meningkat menjadi 3,2 dan pada siklus III meningkat hingga 3,8. Aktivitas siswa juga menunjukkan adanya peningkatan, pada siklus I memperoleh skor rata-rata 2,3. Pada siklus II memperoleh skor rata-rata 2,6 kemudian pada siklus III memperoleh skor ratarata mencapai 3,5. Persentase ketuntasan belajar siswa juga mengalami peningkatan yaitu pada siklus I persentase ketuntasan belajar baru mencapai $44 \%$. Pada siklus II mengalami peningkatan yaitu $67 \%$ dan pada siklus III mengalami peningkatan yang signifikan yaitu persentase ketuntasan belajar mencapai 93\%.

Dengan demikian dapat disimpulkan bahwa melalui model pembelajaran kooperatif tipe Bamboo Dancing dapat meningkatkan kualitas pembelajaran yang meliputi keterampilan guru, aktivitas siswa, dan hasil belajar siswa.

Tabel 1. Data Skor Rata-rata Keterampilan Guru Siklus I, II, dan III

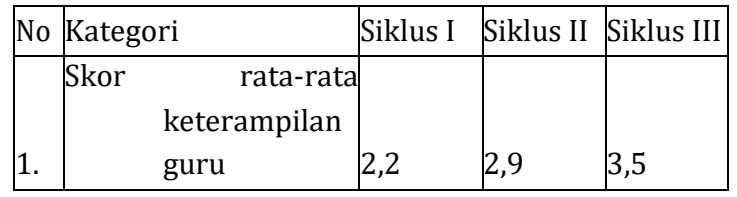




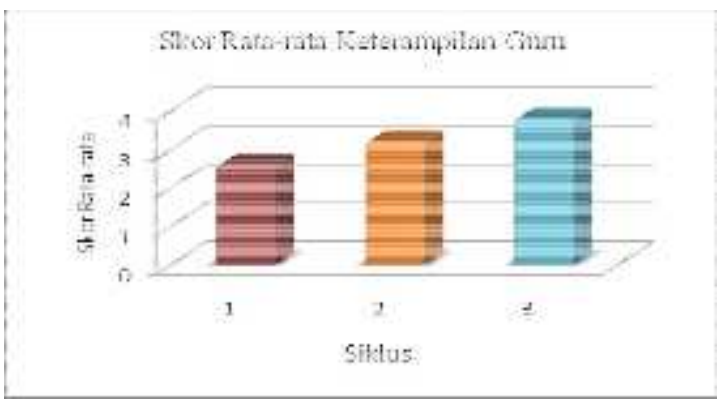

Gambar 1. Diagram Perbandingan Skor Rata-rata Keterampilan Guru

Berdasarkan perbandingan persentase keterampilan guru pada setiap siklus maka dapat disimpulkan bahwa keterampilan guru dalam pembelajaran IPS pada setiap siklus mengalami peningkatan. Pada siklus I skor ratarata keterampilan guru mencapai 2,2 dengan kategori baik , pada siklus II meningkat menjadi 2,9 dengan kategori baik sedangkan pada siklus III meningkat mencapai 3,5 dengan kategori sangat baik.

Tabel 2. Data Skor Rata-rata Aktivitas Siswa Siklus I, II, dan III

\begin{tabular}{|l|l|l|l|l|}
\hline No & Kategori & Siklus I & Siklus II & Siklus III \\
\hline 1. & $\begin{array}{l}\text { Skor rata-rata } \\
\text { aktivitas siswa }\end{array}$ & 2,05 & 2,4 & 3,5 \\
\hline
\end{tabular}

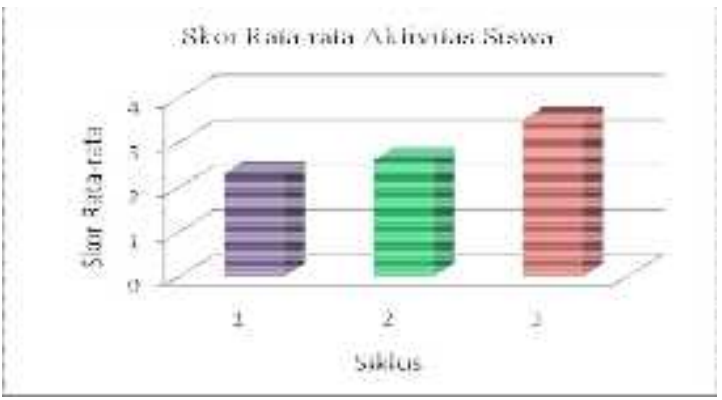

Gambar 2. Diagram Perbandingan Skor Rata-rata Aktivitas Siswa

Berdasarkan diagram di atas nampak bahwa aktivitas siswa dalam pembelajaran selalu mengalami peningkatan. Pada siklus I skor rata-rata aktivitas siswa mencapai 2,05 dengan kategori baik, kemudian pada siklus II meningkat menjadi 2,4 dengan kategori baik. Sedangkan pada siklus III meningkat menjadi 3,5 dengan kategori sangat baik.
Tabel 3. Data Analisis Hasil Belajar Siklus I, II, dan III

\begin{tabular}{|l|l|l|l|l|l|}
\hline No & \multicolumn{1}{|c|}{ Pencapaian } & $\begin{array}{c}\text { Data } \\
\text { Awal }\end{array}$ & $\begin{array}{c}\text { Siklus } \\
\text { I }\end{array}$ & $\begin{array}{c}\text { Siklus } \\
\text { II }\end{array}$ & $\begin{array}{l}\text { Siklus } \\
\text { III }\end{array}$ \\
\hline 1. & Rata-rata & 50 & 66 & 70 & 85 \\
\hline 2. & Nilai Terendah & 30 & 40 & 50 & 55 \\
\hline 3. & Nilai Tertinggi & 80 & 90 & 90 & 100 \\
\hline 4. & Tidak Tuntas & $65 \%$ & $56 \%$ & $33 \%$ & $7 \%$ \\
\hline 5. & Tuntas & $35 \%$ & $44 \%$ & $67 \%$ & $93 \%$ \\
\hline
\end{tabular}

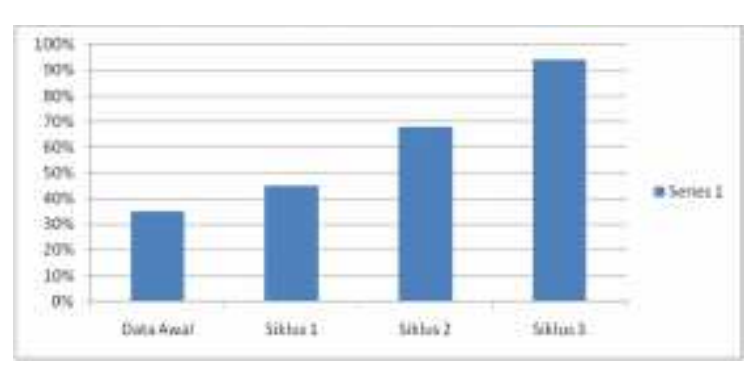

Gambar 3. Diagram Perbandingan Persentase Ketuntasan Hasil Belajar Siswa

Berdasarkan data di atas dapat disimpulkan bahwa dengan menerapkan model pembelajaran kooperatif tipe Bamboo Dancing persentase ketuntasan hasil belajar siswa meningkat pada setiap siklusnya

\section{KESIMPULAN}

Dengan adanya perbaikan pembelajaran, keterampilan guru dalam pembelajaran mengalami peningkatan. Pembelajaran lebih berpusat pada siswa dan guru berperan sebagai pembimbing, fasilitator, dan dinamisator dalam pembelajaran. Peningkatan keterampilan guru ditunjukkan oleh skor rata-rata pada siklus I sebesar 2,2 dengan kategori baik, pada siklus II menjadi 2,9 dengan kategori sangat baik dan pada siklus III menjadi 3,5 dengan kategori sangat baik.

Aktivitas siswa dalam pembelajaran juga mengalami peningkatan, diantaranya siswa lebih antusias dan lebih aktif dalam pembelajaran. Peningkatan ini terlihat pada skor rata-rata pada siklus I sebesar 2,05 dengan kategori baik, skor rata-rata siklus II menjadi 2,4 dengan kategori baik, skor rata-rata siklus III mencapai 3,5 dengan kategori sangat baik.

Hasil belajar siswa mengalami peningkatan pada setiap siklusnya. Persentase 
Romanna Sitindaon, Peningkatan Kualitas Pembelajaran IPS melalui Model Pembelajaran

ketuntasan belajar pada siklus I sebesar 44\%, pada siklus II sebesar $67 \%$, dan pada siklus sebesar 93\%. Dengan demikian dapat disimpulkan bahwa kualitas pembelajaran IPS mengalami peningkatan.

\section{DAFTAR PUSTAKA}

Anitah, Sri dkk. 2009. Strategi Pembelajaran di SD. Jakarta: Universitas Terbuka.

Anni, C. T. 2006. Psikologi Belajar. Tembung : UPT MKK UNNES.

Aqib, Zaenal. 2008. Penelitian Tindakan Kelas. Bandung : Yrama Widya.

Arini, Munisah, Soewarsono, dan Susilo. 2009. Kajian Ilmu Pengetahuan Sosial. Salatiga Widya Sari Press.

Asra, Deni Darmawan, dan Cepi Riyana. 2007. Komputer dan Media Pembelajaran di SD. Jakarta : Direktorat Jendral Pendidikan Tinggi Departemen Pendidikan Nasional.
Baharuddin dan Esa W. 2008. Teori Belajar dan Pembelajaran. Jogjakarta : Ar-Ruzz Media.

Depdiknas . 2004. Peningkatan Kualitas Pembelajaran. Jakarta: Depdiknas.

Dimyati dan Mujiyono. 2009. Belajar dan Pembelajaran. Jakarta : Renika Cipta.

Djamarah, S.B. 2005. Guru dan Anak Didik dalam Interaksi Edukatif. Jakarta : Renika Cipta.

Gulo, W. 2002. Metodologi Penelitian. Jakarta : PT. Gramedia Widiasarana Indonesia.

Mulyani S. dan Johar P. 2001. Strategi Belajar Mengajar. Bandung:CV. Maulana.

Mulyasa, E. 2009. Menjadi Guru Yang Profesional Menciptakan Pembelajaran Kreatif dan Menyenangkan. Bandung : Remaja Rosdakarya

Suprijono. 2010. Cooperative Learning. Yogyakarta: Pustaka Pelaja

Sutikno, M. Subri. 2009. Metode Bamboo Dancing. [online] http://www.google.com/metode bamboo dancing.pdf [13 Mei 2016] 